\title{
To Study the Storability of Phalsa Beverages
}

\author{
S. K. Verma ${ }^{1}$ and Anant Kumar $^{2} *$ \\ ${ }^{1}$ Krishi Vigyan Kendra, Shahjahanpur - 242001, U.P., India \\ ${ }^{2}$ Krishi Vigyan Kendra, Ghaziabad, U.P. \\ (Sardar Vallabhbhai Patel University of Agriculture \& Technology, Meerut, U.P.), India \\ *Corresponding author
}

\section{A B S T R A C T}

\section{Keywords}

Storability, Phalsa beverages, Total soluble solids, Total acidity

\section{Article Info}

Accepted:

10 August 2020

Available Online:

10 September 2020
Beverage i.e. RTS, nectar and squash were prepared from phalsa fruits and studied for their storage stability. The total soluble solids (TSS) of RTS remained unchanged up to two months of storage while nectar and squash did not change in the first month of storage. Total acidity of RTS and nectar did not get altered in the first month of storage. There was slight increase in the level of total acidity in the squash during the storage period. Ascorbic acid content of all the three products declined continuously during the storage. Browning showed a continuous increase in RTS, nectar and squash. Organoleptic score of all the products decreased gradually with the storage period. The qualities of RTS, nectar and squash were found to be acceptable up to four months of storage.

\section{Introduction}

Phalsa (Grewia subinaequalis D.C.) is a minor fruit crop grown in semi-arid tropics of sub-tropical regions of India. The fruits contain fair amount of juice, high total soluble solids, total minerals and ascorbic acids. Its fruits have attractive colour and pleasing flavor. However, fruits are highly perishable in nature and can not be stored for more than 2-3 days at ambient temperature. Hence they are required to be processed in to various quality products particularly beverages, which are highly refreshing, easily digestible, invigorating, thirst quenchers and appetizers. Phalsa, is gaining popularity among the consumers due to its high neutro-clinical values, in rural as well as urban masses. In addition, the ripe fruits are good source of sugars, vitamins and minerals. The ripe berries used for inflammation, blood disorders and constipation. In Unani medicine it is considered to be beneficial for heart, diarrhoea and fever (Singh, 1966). However, the short shelf life of fruits made it available only for short period, which make its popularities unrealized. The untapped popularity of phalsa fruits can be harnessed 
by processing in to fine products like RTS, nectar and squash. The meager information is available on changes occurring during storage of phalsa beverages. Therefore, the present investigation was carried out to study the storage stability of phalsa beverage.

\section{Materials and Methods}

The present investigation carried out at the Processing Unit, Krishi Vigyan Kendra, Shahjahanpur, Uttar Pradesh under Sardar Vallabhbhai Patel University of Agriculture and Technology, Meerut in the year 2017-18 and 2018-19. The fruits of phalsa var. Sharbati were used for experimentation. The extraction of juice was done manually and fruit to water ratio used for extraction of juice was 1:0.25. The total soluble solids of extracted juice were determined with the help of hand refractrometer and value corrected at 20 DC. Acidity was determined by titrating the juice against N/10 NaOH and expressed as per cent citric acid. Ascorbic acid and nonenzymatic browning were analysed according to the method suggested by Ranganna (1986). The different recipes of phalsa beverage i.e. RTS, nectar and squash were prepared and subjected for organoleptic evaluation so as to find out an ideal recipes (Table 1). The organoleptic evaluation was done by Hedonic Rating scale as given by Amerine et al., (1965).

The RTS and nectar of the recipe adjusted the best was bottled ( $200 \mathrm{ml}$ capacity) by leaving $2 \mathrm{~cm}$ head space and pasteurized for 20 minutes in boiling water and cooled in air. Squash preserved with $350 \mathrm{ppm}$ of $\mathrm{SO}_{2}$ was filled in sterilized bottle ( $750 \mathrm{ml}$ capacity) and sealed immediately. These bottles were stored at ambient temperature for further studies. Observations were taken just after preparation of the products and thereafter one month tell the 5 th months of storage.

\section{Results of Discussion}

Changes during storage of phalsa beverages indicated that TSS increased slightly after 2, 1 and one month in RTS, nectar and squash respectively (Table 2). An increase in TSS content of phalsa fruit products during storage may possibly due to conversion of polysaccharides into sugars. Similar observations were also recorded by Khurdiya (1979) and Kannan et al., (2001) in phalsa RTS.

Total acidity of Phalsa RTS and nectar did not alter after one month of storage and thereafter, a slight increase was observed upto end of storage. Whereas, acidity of squash was found to increase right from the beginning of storage (Table 3). Conn and Stumpt (1976) are reported that pectic substances are the responsible for the increase the acidity of fruits. Hence, in the present study degradation of pectic substances in to soluble solids might have contributed towards an increase in the acidity of products.

Ascorbic acid content of all the three products decreased continuously during entire period of storage (Table 4). This reduction might be due to oxidation of ascorbic acid in to dehydroascorbic acid by oxygen. Several authors have also recorded losses of ascorbic acid in fruits beverages during storage [Sethi et al., (1980); Ghosh et al., (1982); Bube, (1984); Ram (1984)].

The colour and flavour are the most important quality parameter for the fruit beverages. Deterioration of colour due to enzymatic and non-enzymatic pigment during storage of fruit products impairs the quality of the products. The present study revealed that the browning of RTS, nectar and squash increased continuously throughout the entire period of storage (Fig. 1). 
Table.1 Specifications for different phalsa beverages

\begin{tabular}{|l|c|c|c|}
\hline Beverages & Juice (\%) & TSS (\%) & Acidity \\
\hline RTS & 10 & 12 & 0.30 \\
\hline Nectar & 20 & 13 & 0.30 \\
\hline Squash & 25 & 45 & 1.2 \\
\hline
\end{tabular}

Table.2 Changes in total soluble solids (\%) during storage of phalsa beverages

\begin{tabular}{|c|c|c|c|}
\hline $\begin{array}{c}\text { Storage period } \\
\text { (months) }\end{array}$ & RTS & Nectar & Squash \\
\hline 0 & 12.00 & 14.00 & 45.00 \\
\hline 1 & 12.00 & 14.00 & 45.00 \\
\hline 2 & 12.00 & 14.38 & 54.50 \\
\hline 3 & 12.19 & 14.42 & 45.98 \\
\hline 4 & 12.44 & 14.60 & 47.00 \\
\hline 5 & 13.51 & 16.20 & 47.10 \\
\hline
\end{tabular}

Table.3 Changes in total acidity $(\%)$ during storage of phalsa beverages

\begin{tabular}{|c|c|c|c|}
\hline $\begin{array}{c}\text { Storage period } \\
\text { (months) }\end{array}$ & RTS & Nectar & Squash \\
\hline 0 & 0.25 & 0.30 & 1.20 \\
\hline 1 & 0.25 & 0.30 & 1.23 \\
\hline 2 & 0.28 & 0.34 & 1.25 \\
\hline 3 & 0.30 & 0.37 & 1.29 \\
\hline 4 & 0.31 & 0.41 & 1.36 \\
\hline 5 & 0.39 & 0.45 & 1.40 \\
\hline
\end{tabular}

Table.4 Changes in ascorbic acid (mg/100 ml) of juice during storage of phalsa beverages

\begin{tabular}{|c|c|c|c|}
\hline $\begin{array}{c}\text { Storage period } \\
\text { (months) }\end{array}$ & RTS & Nectar & Squash \\
\hline 0 & 2.80 & 5.18 & 8.45 \\
\hline 1 & 2.68 & 5.02 & 7.90 \\
\hline 2 & 2.37 & 4.49 & 7.45 \\
\hline 3 & 1.77 & 3.68 & 6.49 \\
\hline 4 & 1.39 & 2.99 & 5.19 \\
\hline 5 & 1.21 & 2.39 & 4.50 \\
\hline
\end{tabular}


Fig.1 Changes in browning (O.D.) during storage of phalsa beverages

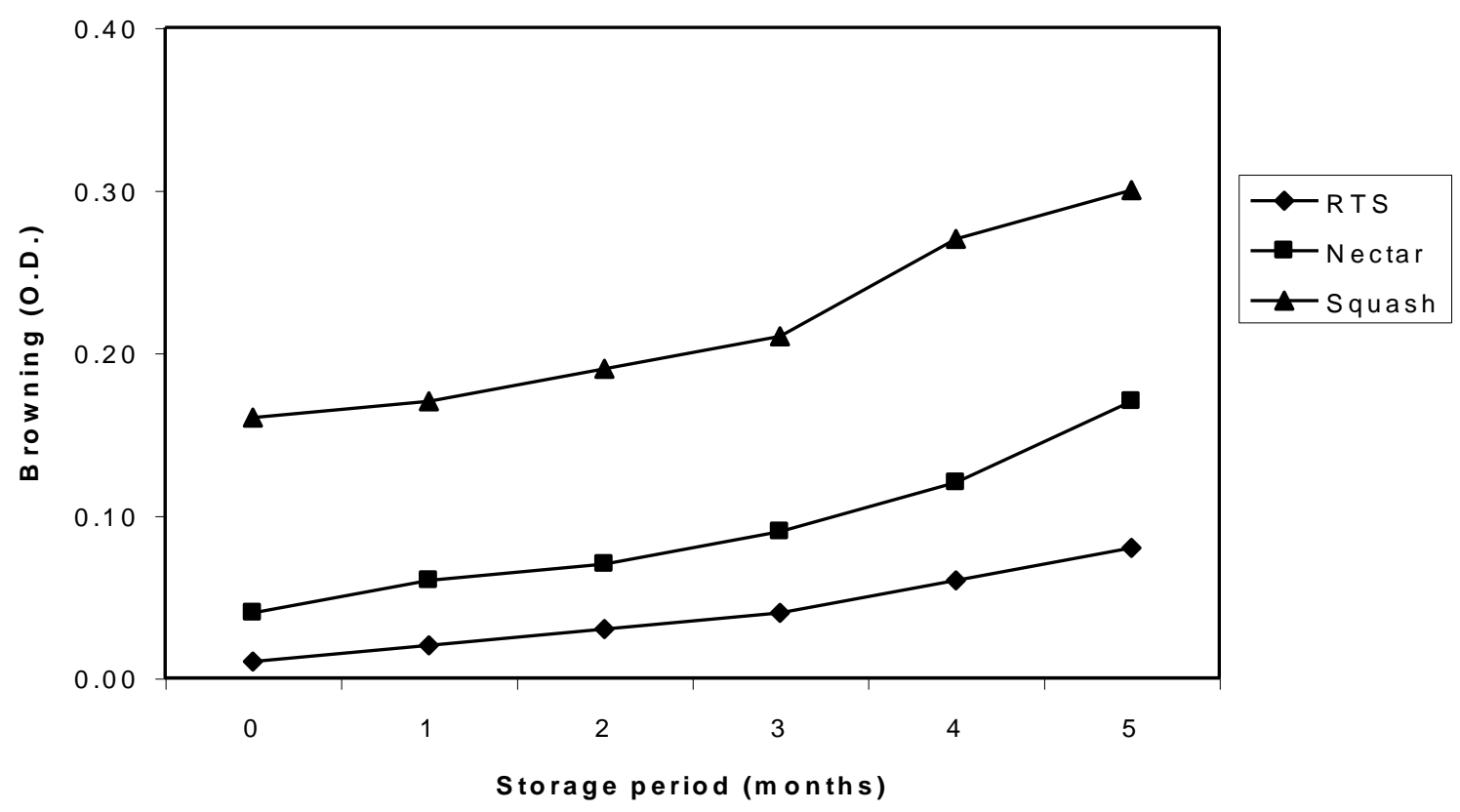

Fig.2 Changes in organoleptic quality of phalsa beverages during storage

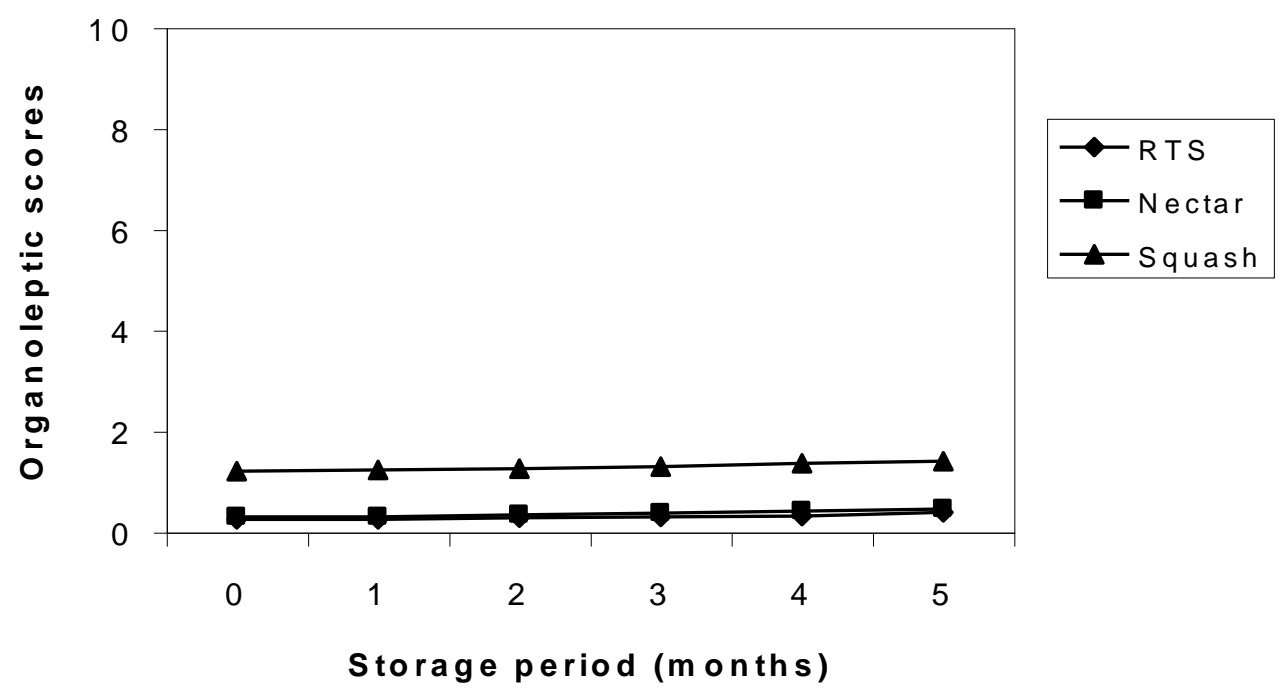

It could be attributed to non-enzymatic reactions, which occur between nitrogenous compounds and sugars or organic acid and organic acids with sugar. Earlier Kapoor et al., (1958) reported that reactions between organic acids and sugars are responsible for browning. Results also indicated that browning was less in RTS than in nectar and squash. This may possibly be due to higher concentration of sugar and organic acids in nectar and squash.

Colour, aroma and taste of the product can be measured organoleptically and they are most important quality attributes. Organoleptic quality determines the storage stability of 
product. In the present finding these was a gradual decrease in organoleptic score of phalsa beverages during storage at room temperature (Fig. 2). The acceptability of all the three products was maintained up to 4 months.

It is concluded that the, present investigation provides ample evidences that phalsa fruit beverages can be safely stored up to four months with acceptable quality.

\section{References}

Amerine, M.A., Panghorn, R.M. and Roesseter, E.B. 1965. Principles of sensory evaluation of Foods. Academic Press, New York.

Conn, E.E. and Stumpt, P.K. 1976. Outlines of Biochemistry. Willey Eastern Ltd., New York.

Dhawan K, Malhotra S, Dhawan SS, Singh D, Dhindsa KD. Nutrient composition and electrophoretic pattern of protein in two distinct types of phalsa (Grewia subinequalis DC). Plant Food Hum. Nutr. 1993; 44:255- 260.

Dube, K.P. 1984. Studies on preparation and preservation of Bael (Aegle marmelos Corn.) beverages. M.Sc. thesis, N.D. Univ. of Agri. and Tech., Faizabad.

Ghosh, K.C., Nirmala, M., Krishnappa, K.G., Parmeshwari, P.M., Broken, H. and Vijayaraghyan, P.K. 1982. Preservation of fruit juice and pulp in flexible pouches. Indian Food Packer, 36(4) : 23-26.

Kannan, S. and Thirumanan, A.S. 2001. Studies on storage life of Jamun products. Indian Food Pacter. 55(6): 125-127.

Kapoor, N.S.; Bhatia, B.S. and Lal, G. 1958. The non-enzymatic browning of food products; sugar organic acid model system. Food Science (Mysore), 7: 181.

Kathrotia RK, Singh SP. Regeneration of roots in phalsa (Grewia asiatica) stem cuttings as influenced by maturity of wood and root promoters. Adv. Hort. For., 1995; 4:35- 41.

Khurdiya, D.S. 1979. Nature and relation of anthocyanin pigments in Phalsa juice.

Ph.D. thesis, IARI, New Delhi.

Morton JF. Phalsa. In: Fruits of warm climates. Julia Morton, Miami, FL, 1987, 276-277.

Pujari S. Phalsa Cultivation in India Production Area, Climate, Harvesting and Fruit Handling, 2012. http://www.yourarticlelibrary.com/cultiva tion/phalsacultivation-in-indiaproduction-area-climate-harvestingandfruit handling/24703.

Raganna, S. 1986. Manual for analysis of fruit and vegetative products. Tata McGraw Hill Pub. Co., New Delhi.

Ram, B. 1984. Studies on processing and preservation of aonla (Emblica officinalis) beverages. M.Sc. thesis, N. D. Univ. of Agri. \& Tech., Faizabad.

Sethi, V., Anand, J.C. and Saxena, S.K. 1980. Kinnow orange in juice and beverage making. Ind. Hort. 25: 13.

Shrivastava SR. Effect of IBA, sugur and captan on rooting of phalsa (Grewia subinaequalis DC). Recent Horticulture. 1996; 3(1): 52-54.

Singh, I.J. 1966. Phalsa - a home garden fruit. Ind. Hort. 10(3): 3-4.

Yadav AK. Phalsa: A Potential New Small Fruit for Georgia. In Perspectives on New Crops and New Uses; Janick, J., Ed.; ASHS Press: Alexandria, USA, 1999, 348-352.

\section{How to cite this article:}

Verma, S. K. and Anant Kumar. 2020. To Study the Storability of Phalsa Beverages. Int.J.Curr.Microbiol.App.Sci. 9(09): 1026-1030. doi: https://doi.org/10.20546/ijcmas.2020.909.127 